\title{
Chico Buarque e a urgêNCiA QUE MOVE ESSA GENTE ${ }^{1}$
}

Chico Buarque and the uRGENCY

THAT MOVES ESSA GENTE

\section{Luis Eduardo Veloso Garcia}

ORCID 0000-0003-3467-2561

Universidade Estadual do Norte do Paraná, Jacarezinho, PR, Brasil

Lançado em 2019, o último romance de Chico Buarque (o primeiro após ser laureado com o Prêmio Camóes), intitulado Essa Gente, é um retrato importante das concepçóes sociais que marcam o Brasil no tempo presente. $\mathrm{O}$ quadro que se apresenta na obra, com os espaços contrastados do Rio de Janeiro formado por um Leblon e um Vidigal cada vez mais distantes, é a expressão de um país inteiro que se alimenta, cada vez mais, de indiferença e violência.

Com uma carreira fortemente consolidada, cada incursão de Chico Buarque na literatura gera uma enorme repercussão, fundamentalmente movida pela busca de elementos autobiográficos dentro das obras, afinal, trata-se de uma figura que tem forte presença no imaginário coletivo do país, sendo um dos maiores nomes de nossa cultura.

Se em algumas obras literárias Chico Buarque explora a autoficção, como é o caso do penúltimo livro intitulado O Irmão Alemão, em outras ele se adentra em uma crítica social contundente, como ocorre com sua dramaturgia ou em uma novela como Fazenda Modelo. Podemos dizer que há traços autoficcionais em Essa Gente, porém, não com o intuito de discutir esse "jogo de cena" - expressão usada por Karl Erik Shøllhammer sobre a autoficção em um dos capítulos do seu livro Ficção brasileira contemporânea (2009) -, mas sim de propor uma representação crítica e detalhada do quadro político e social do nosso presente, mirando a gritante desigualdade e os discursos que a naturalizam, principalmente para moradores do Leblon como Manuel Duarte, o protagonista da obra, e Chico Buarque.

Talvez a palavra que melhor represente este romance seja "urgência", como se $\mathrm{o}$ artista quisesse dar retrato e nomes ao presente inquietante que (n) $o$ (s) cerca. Sua preocupação maior não é com a criação de uma história que busque cativar o leitor (como vemos na busca de seu irmáo bastardo em $O$ Irmão Alemão, ou na proximidade angustiante da morte em Leite Derramado),

1 Resenha de: BUARQUE, Chico. Essa gente. São Paulo: Companhia das Letras, 2019. 
mas sim em criar um espelho incômodo: "Essa gente" do título não é um grupo desconhecido de nós, afinal, os discursos que as personagens carregam são legitimados em nosso cotidiano o tempo todo; "Essa gente" do título são nossos conhecidos (vizinhos, parentes e amigos) e, consequentemente, nós mesmos, o próprio leitor; "Essa gente" do título é quem repete e, também, quem é conivente ao discurso de desigualdade, principalmente por não confrontá-lo; "Essa gente" do título somos nós confirmando a posição de privilegiados por termos acesso a obras literárias como essa, diferente da grande parte da população que não tem a mínima possibilidade desse acesso; "Essa gente" do título são os bolsonaristas que odeiam Chico Buarque e, também, os buarquistas que odeiam Bolsonaro no alto de sua condição de privilegiado, inclusive para ir embora do país caso tenha vontade.

A urgência é tão grande para a obra que temos impresso em sua própria capa o texto integral do livro em letras vermelhas bem pequenas, como se a pressa que nos consome na contemporaneidade não desse a possibilidade de desacelerar e abrir um livro para usufruí-lo calmamente, como se tudo que o livro pode nos dizer já estivesse em sua própria capa: nesse caso, está mesmo.

É preciso nos debruçarmos no presente de Chico Buarque que, como figura pública, abre caminhos para conhecermos o que ocorre com ele através dos noticiários e, principalmente, interpretarmos a urgência que o leva a escrever esse livro. Como é de conhecimento de todos, após declarar apoio a Lula e Dilma nas eleiçóes anteriores e manter falas de apoio aos dois e, obviamente, a pautas direcionadas aos movimentos de esquerda, ele virou um dos principais alvos de ódio declarado do grupo de apoiadores do novo governo em questão, a ponto de agressóes da milícia virtual (muitas vezes, recorrendo ao expediente das Fake News, prática comum do grupo) e até mesmo agressóes públicas (como a ocorrida em um restaurante no Leblon em 2015) se tornarem recorrente em sua vida.

O próprio presidente da república proferiu diversas ofensas diretas ao artista, sendo o seu maior ato de reprovação à pessoa do autor a decisão de não assinar o diploma do Prêmio Camóes, com a irônica justificativa de que até o 31 de dezembro de 2026 ele teria prazo para assinar ${ }^{2}$. A urgência de não deixar seu algoz com a sensação de vencedor fez com que o autor respondesse que a não assinatura do Bolsonaro no diploma era para ele um segundo Prêmio Camóes ${ }^{3}$.

O livro Essa gente traz, também, essa urgência de não deixar sem resposta aqueles que o atacam; afinal, encontramos todos os discursos e ofensas lançadas a Chico Buarque dentro da obra, incluindo uma piada direta com o próprio presidente, transformando-o em um boneco dourado exposto ao

2 Ver edição de Istoé de 09/10/2019

3 Ver edição do Portal G1 de 9/10/2019 
público carioca em uma varanda do Leblon, mais especificamente a varanda da ex-mulher do protagonista.

Para compreender mais claramente quem é, então, "essa gente" representada pelo autor, torna-se necessário nos atermos a algumas personagens que ganham maior destaque: o protagonista Manuel Duarte, que se trata de um romancista renomado no país, suas ex-mulheres Maria Clara e Rosane, seu filho Agenor e, consequentemente, os moradores do mesmo prédio em que vive no Leblon e figuras conhecidas dos arredores.

Apesar das separaçôes, as ex-mulheres são bastante presentes na vida da personagem principal. No entanto, suas personalidades se mostram completamente opostas, com Maria Clara sendo uma crítica ferrenha ao atual governo, enquanto Rosane se declara uma fấ convicta de todos os ideais bolsonaristas. Elas nos dão a exata medida dos extremos em conflito, com Duarte procurando manter as vantagens possíveis ao conviver com as duas. Sim, Duarte é aquele que não se expóe defendendo nem um lado e nem o outro das faces da moeda política atual, com uma postura isenta na qual sai, aparentemente, no lucro.

Maria Clara direciona seus incômodos para a situação da política atual em diálogos diretos que apontam tanto o receio com as pessoas que a cercam - "sinto falta de um amigo com quem partilhar meu inconformismo em relação ao que estão fazendo com nosso país. Será que ainda teremos nossa correspondência violada? Será que ainda incendiarão os nossos livros?” (BUARQUE, 2019, p. 35) - quanto pela postura do próprio ex-marido e o risco que isso pode causar na educação do filho deles:

Confio em que tomes tuas providências sem tardança, pois de nossa parte estamos tratando da mudança para Lisboa. Laila acredita que o ambiente no país em breve se tornará insuportável para gente de esquerda como ela e intelectuais em geral como eu. Até pouco tempo atrás, tu também podias ser enquadrado, com reservas, tanto em uma quanto em outra categoria. Já agora que cultivas relaçôes privilegiadas, nos círculos que passaste a frequentar, estás incólume a iras e riscos. [...] Só te peço um favor: se eventualmente fores convidado para alguma festa junina, ou quem sabe um banho de piscina em casa dessa corja, não me dês o desgosto de levar meu filho. (BUARQUE, 2019, p.149)

Rosane anuncia seus incômodos para os críticos da situação da política atual que ridicularizam e "torcem contra" a figura do presidente idolatrado por ela ao ponto de ganhar uma estátua dourada - "Que boneco? Ah, você está falando da estátua. Que é que tem? Ridículo é você. Que lençol o que, eu não vou cobrir meu presidente com lençol. Quer secar o homem?" (BUARQUE, 2019 , p. 57) - e defende todos os apoiadores dessa perspectiva ideológica, 
vendo neles a voz da razão: "Agora para você é todo mundo fascista. Você conhece ele? Pois é super boa gente" (BUARQUE, 2019, p. 79).

Agenor, o salva-vidas que resgata Duarte do afogamento, terá uma função fundamental na obra: servir de duplo espelho para o autor. Primeiro, ele refletirá os contrastes possíveis de um morador do Vidigal que se torna amigo de um morador do Leblon, convidando o romancista para frequentar aquele espaço (importante ressaltar que não ocorre o convite inverso, demonstrando simbolicamente as distâncias que não se quebram: Duarte nunca chama Agenor para sua casa).

Na sequência, temos em sua figura o reflexo que se tornará a principal crítica do livro, pois ela se confirmará no impactante desfecho da obra: o olhar para o negro em uma sociedade que, como nos lembra bem Djamila Ribeiro em seu Pequeno Manual Antirracista, mantém o racismo de maneira estrutural na qual "a posição social do privilégio vem marcada pela violência, mesmo que determinado sujeito não seja deliberadamente violento" (RIBEIRO, 2019, p. 33). "Essa gente" se alimenta física e simbolicamente de diminuir o negro para se colocar em uma posição superior.

O primeiro trecho que recorto para dar essa exata noção, e que traz bem as ideias de Djamila Ribeiro quando ela discute na obra citada o mercado cultural brasileiro nos capítulos "Leia autores negros" e "Questione a cultura que você consome”, refere-se tanto à descriçáo de Agenor feita pelo romancista dentro do livro quanto pelas bases do jogo autoficcional que Chico Buarque, aparentemente, nos propóe:

Após o pernoite no hospital, passo em casa para vestir umas bermudas, volto à praia, e no mirante do posto de salvamento procuro o guarda-vidas que me socorreu. $O$ sargento Agenor é um negro bonito de presumiveis quarenta anos, se bem que os da sua raça geralmente parecem mais jovens do que são. [...]

- Você quer contar minhas histórias?

- Posso inventar mais algumas, se você permitir.

- E se eu não gostar?

- Troco seu nome.

- $\mathrm{E}$ as suas histórias você também inventa?

- Claro, no meu livro posso ser quem eu quiser. Posso até te salvar de um afogamento.

- Você no livro é branco ou preto?

- Hein?

- Épreto ou branco?

- Boa pergunta.

Percebo que nos romances nunca me preocupei em explicitar a minha cor. $\dot{E}$ curioso que, num pais onde quase todo mundo é preto ou mestiço, autor nenhum 
escreveria "hoje encontrei um branco...", ou "um branco me cumprimentou...", ou "o sargento Agenor é um branco bonito de presumiveis quarenta anos, se bem que os da sua raça...”. (BUARQUE, 2019, p.60-61, grifo nosso)

Ser negro em frente a "essa gente" é ser o alvo predileto para a morte, com a ordem vigente do estado trabalhando claramente no exercício dessa confirmação: "Um preto desata a correr, estava demorando. Dez, vinte banhistas correm atrás. Agarram o preto, vão linchar. Chegam dois PMS pardos e isolam o preto. É deles o direito de bater no preto" (BUARQUE, 2019, p. 152).

Ser negro em frente a "essa gente" é ver a celebração de sua morte com selfies e felicitaçóes para quem fizer esse trabalho de os eliminar, refletindo nas redes sociais desse grupo com diversas curtidas e compartilhamentos:

Aparentemente a fim de se entregar, o assaltante solta o porteiro e abaixa a arma, mas de repente sacode a cabeça e cai duro no cháo. Foi um tiro na testa que tomou, disparado talvez de alguma janela vizinha por um atirador de elite. Deitado de costas, se contorce inteiro ao levar mais uns tantos tiros à queima-roupa. Depois que se aquieta, os meganhas continuam baleando o cara, na barriga, no peito, no pescoço, na cabeça, eles o matam muitas vezes, como se mata uma barata a chineladas. Aos hurras e aplausos, os espectadores descem dos prédios e dos carros e correm para o palco da façanha. $\mathrm{O}$ policial do megafone retira de um golpe o capuz ensanguentado do sujeito, e na sua cara deformada reluto em identificar meu conhecido, o passeador de cáes. A polícia não consegue impedir que os presentes chutem seu corpo, e estremeço ao ver meu filho a se aproximar. Consigo desviá-lo do morto, mas ele só quer se juntar aos policiais, que posam para selfies com seus admiradores. (BUARQUE, 2019, p. 70)

Ser negro em frente a "essa gente" é se sentir no tempo presente, mesmo que com um certo poder aquisitivo, olhado dessa forma pelos outros que vivem nos espaços mais privilegiados, principalmente quando se trata de um dos bairros mais ricos de uma capital como o Rio de Janeiro:

Nos seus recintos, porém, durante anos cheguei a ser feliz, casei, tive amantes, comi, bebi, joguei pôquer com amigos, frequentei escritórios, consultórios, papelarias, cabeleireiros, sapatarias e tal. Ultimamente não mais, é como se eu viesse de uma temporada fora, e na minha ausência o restaurante tivesse virado uma farmácia, a farmácia um banco, o banco uma lanchonete, e a população tivesse sido substituída por outra, que me torce o nariz como a um imigrante, um pobretão. (BUARQUE, 2019, p. 20) 
A postura isenta é, também, uma defesa daquele que sente a hostilidade de viver no Leblon com "essa gente" que não o aceita (que o quer expulsar para as margens da cidade, como na música "As Caravanas", do último disco de Chico Buarque), levado, cada vez mais, ou a matar (uma indiferença e violência que, com o fervor da desigualdade social, gerará mais violência) ou a morrer.

Manuel Duarte é negro e só descobrimos isso, claramente, no desfecho da obra, quando a morte o encontra. A releitura do livro ganha um efeito ainda maior, pois conseguimos confirmar as pistas provocadoras que o autor deixa na trajetória da protagonista. É no julgamento dos vizinhos, no olhar que "essa gente" lança para o seu corpo morto que se condensam os discursos de imensa indiferença e violência que precisam ser extintos, com urgência, em nossa sociedade táo desigual:

Retirada gentilmente pelo delegado, a dra. Zabala descreve a fisionomia do defunto, os olhos vidrados, a mandíbula torta e uma estranha coloração verde-escura. Não custa a circular no hall a informação de que o escritor do 702 era mulato, apesar dos desmentidos da própria juíza, para quem nunca houve um inquilino afrodescendente no Edifício Saint Eugene. Os moradores fazem silêncio finalmente, quando o corpo sulfuroso deixa o apartamento dentro de um saco preto, sobre uma maca de aço carregada pelos bombeiros: dá licença, dá licença. Assim que eles descem pela escada, alguém comenta que crioulo, quando náo caga na entrada, caga na saída. (BUARQUE, 2019, p.189)

\section{Referências}

BUARQUE, Chico. Essa gente. São Paulo: Companhia das Letras, 2019.

RIBEIRO, Djamila. Pequeno manual antirracista. São Paulo: Companhia das Letras, 2019.

SCHØLLHAMMER, Karl Erik. Fiç̧ão brasileira contemporânea. Rio de Janeiro: Civilização Brasileira, 2009.

Luis Eduardo Veloso Garcia. Professor no curso de Letras da UENP (Jacarezinho-PR). Doutor em Estudos Literários pela UNESP/Araraquara e Mestre em Estudos Literários pela UEL.

E-mail: luis.garcia@uenp.edu.br

Recebido em: $14 / 01 / 2020$

Aceito em: 13/08/2020 